\title{
Methodology of calculating risk premiums in the environment of the Czech Republic and its comparison with Damodaran
}

\author{
Jiri Kucera ${ }^{1,{ }^{*}}$ and Lenka Maskova ${ }^{2}$ \\ ${ }^{1}$ University of Zilina, The Faculty of Operation and Economics of Transport and Communications, \\ Department of Economics, Univerzitna 8215/1, 01026 Zilina, Slovakia \\ ${ }^{2}$ Institute of Technology and Business, School of Expertness and Valuation, Okruzni 517/10, 37001 \\ Ceske Budejovice, Czech Republic
}

\begin{abstract}
Investors' decisions are largely influenced by the riskiness of the country. Several different approaches are available to calculate this risk, but even so, the values set by Damodaran are usually used, even for non-US states. The aim of the paper is to propose a methodology for creating a risk premium in the environment of the Czech Republic and then compare it with Damodaran [1]. Methods applicable in the Czech Republic and Damodaran methods are used, then these methods are compared. For Czech as well as foreign investors, the easiest way to obtain a risk premium is to use the company's investment rating. In the case of determining the risk premium of the Czech Republic, the easiest method is the CRP (country risk premiums) model. If the country's market does not have a long history or does not have such a developed capital market, it is recommended to apply data from the US capital market. However, there are significant differences in the economy between Europe and the USA, so the data of an European country such as Germany, which has historical risk premium calculations, should be used.
\end{abstract}

Keywords: risk premium, risk countries, Damodaran's methods, rating, CRP

\section{Introduction}

Recently, foreign investment has been growing. Investors make their decisions based on the reward they receive for taking the risk of making an investment. The efficiency of the investment is related directly to the risk, also called the risk premium, which is included in the discount rate [2].

According to Damodaran [3], a financial theorist, risk is characterized in terms of the difference between actual and expected returns. The investment is risk-free if the actual returns are always the same as the expected returns. The risk premium is what investors require on average as a premium for risk-free investment rate with an average risk for each factor.

\footnotetext{
*Corresponding author: kuceraj@mail.vstecb.cz
} 
Kruschwitz et al. [4] mention the Country Risk Premiums (CRP) calculation model proposed by Damodaran. This model also influences the investor's decision on the appropriate placement of capital. There are different ways to assess country risk, but the simplest method would be to use the ratings of the relevant agencies. Although Damodaran's model is applied in many countries, it is criticized by several theorists. Marik and Marikova [5] state that this model requires a database containing, if possible, longer time series. However, the problem is that the Czech capital market does not provide the necessary statistically sufficient database. Both Czech and foreign investors who would like to invest in the Czech Republic have this problem.

The aim of this paper is to propose a methodology for creating a risk premium in the environment of the Czech Republic and then compare it with Damodaran [1].

\section{Literature research}

\subsection{Risk premiums}

Damodaran [1] characterized the risk premium as an essential and critical part of portfolio management, business finance and valuation. Given its importance, it is surprising that estimation issues are not given much attention in practice. The Equity Risk Premium, ERP, is specified by Damodaran [6] as the price of risk on the stock markets and is also a key input in estimating the cost of capital and capital in business finance and valuation. It is also a central part of the risk and reward model in finance. According to Chen [7], all financial funds are based on the claim that investors do not like risk and therefore demand higher returns as compensation for risk-bearing. The equity risk premium can be considered as an additional rate of return that investors consider to be returns in exchange for a burden bearing volatility and the associated risk of loss. Economists are still looking for a simple model that justifies the premium given the much lower volatility of aggregated economic data. According to Siegel [8], the search for the right equity risk premium model has yielded insights that can help professionals structure their clients' portfolios. First, habit formation means that the investor's short-term and long-term attitudes to risk may differ. Second, the investor's earnings can cause significant differences in asset allocation. Third, the idea that risk aversion becomes extremely high at low levels of consumption has prompted "investing in liabilities." Investors, especially the older generation, finance what they consider to be the absolute minimum expenditure on risk-free assets and allocate the remainder according to the usual risk.

According to Damodaran [9], risk can be both a threat to a company's financial health and an opportunity to have an advantage over competition. Most analysts focus on the threat when managing risks and emphasize protection against that threat. The risk associated with an investment is generally reflected in the discount rate used in conventional discounted cash flow models. Kliestik, Kocisova and Misankova [10] therefore also focused on the analysis of methods for predicting the failure of society on the basis of publicly available data. Failing companies thus become high-risk for investors. Kliestik [11] further extended this topic to predict the financial health of a company based on mathematical methods.

Furthermore, Damodaran [1] argued that the premiums that are estimated can vary widely in different approaches. Three approaches are used to estimate equity risk premiums. The first is the exploratory approach, where investors or managers are asked to provide estimates of the equity risk premium for the future. Another is a historical return approach, where the bonus is based on how well the stock has performed in the past. The last is the implied approach, where future cash flows are used to estimate the current equity 
risk premium. Corelli [12] also adds that the estimate of the equity risk premium comes only after a careful analysis of the individual factors that determine it.

\subsection{Country risk premium}

The term rating is used in connection with country risk assessment. The Ministry of Finance of the Czech Republic [13] describes the country's rating as an assessment of its creditworthiness and economic ability to meet its own obligations, but also as a synthetic expression of the quality of the Czech state as a debtor. Potential investors rely not only on their own judgment, but especially on the country's rating.

An Aaa-rated country is considered almost risk-free, while a C-rated country is very risky [14]. For the most part, rating companies agree in their ratings, but there may be significant differences between ratings of the countries. These differences may result from different assessments of political and economic risk. The Czech National Bank [15] compiled a clear table 1, which is given in the appendix, with scores ranging from the best, AAA to the worst, CC. The country ratings from three rating agencies, referred to as the "Big Three" - Moody's, Standard \& Poor's and Fitch, are recognized and used around the world. These agencies work with the central bank and ministries of a particular country. Current information on the rating of individual countries dates from January 2020. According to the table of rating agencies, the Czech Republic belongs to the group with the rating score Aa3, or also AA-. It is therefore the only country in the former Eastern bloc to achieve a high rating.

In 2019, the international rating agency Standard \& Poor's confirmed the excellent rating of the Czech Republic for long-term liabilities. The agency positively assessed mainly the low indebtedness of the public sector, but also healthy economic growth. According to them, the Czech Republic is currently one of the European Union countries with the lowest share of government debt to GDP [13].

In the same year, Fitch also confirmed the country's high creditworthiness. Confidence in the Czech Republic is based on strong public finances, a stable banking sector and low indebtedness. The country is considered a net foreign creditor. Based on three scales of the rating agencies, Chart 1 shows the historical development of the Czech Republic's rating from 1992 to 2020 . Historically, the country received the first rating in 1992. The chart shows that, according to S\&P, the rating has been stable since 2011 . 


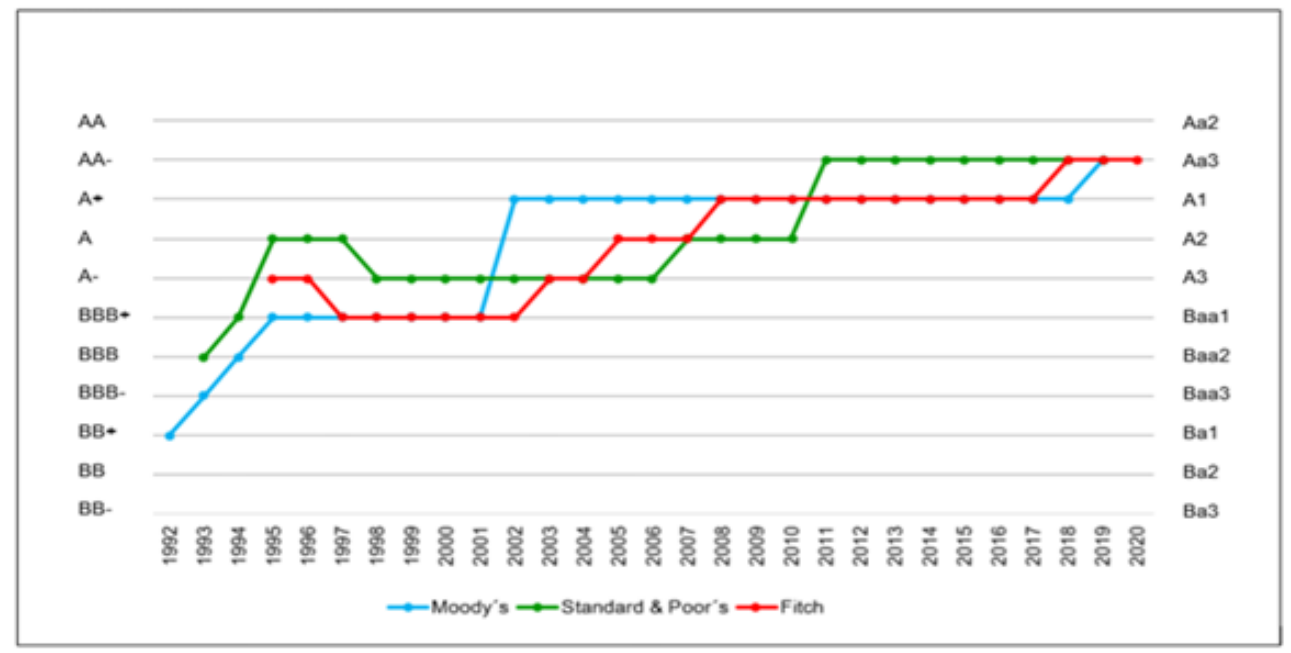

Fig. 1. Rating history of the Czech Republic

Source: Authors, according to Czech National Bank [16].

The credit insurance company Euler Hermes [17] published individual risks, which are assessed in a country's risk. The overall risk assessment is based on two elements - an ongoing assessment of the country and a short-term assessment of the business environment. This data is valuable information when making decisions to potential investors.

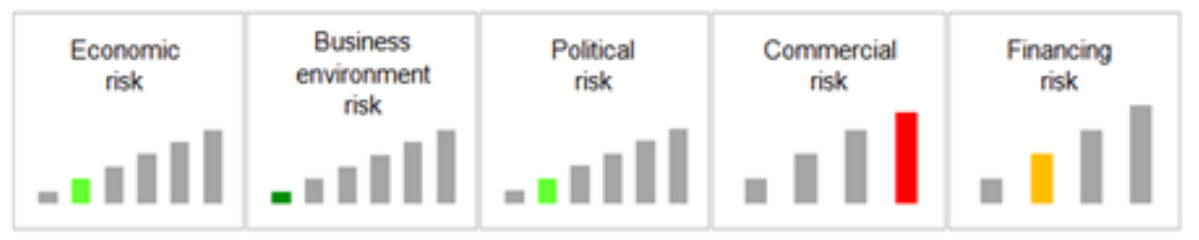

Fig. 2. Individual risks

Source: [17].

When investing in emerging markets, country risk is important and is a key part of estimating the capital cost of investment. Investors in developed countries can diversify country risk fluctuations, and therefore risk does not require an additional premium [18].

In Figure 1 below, the current country risk assessment map is divided into four levels on a scale from low to very high. These levels are based on four components, which are analyzed globally for all economic sectors [17]. These are demand, profitability, liquidity, and the business environment. The map also shows the Czech Republic, which has a low risk score. It is therefore on the same level as, for example, the United States of America, Australia or Western and Northern Europe. 


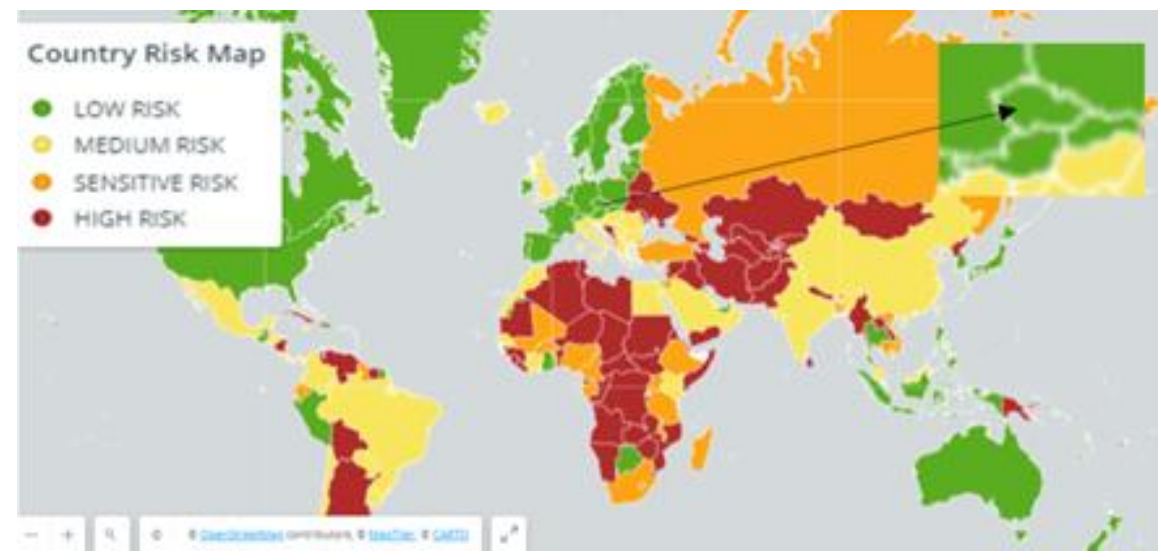

Fig. 3. Country risk assessment map

Source: [17].

Palic, Posedel and Vizek [19] point out that the "overheating" of the economy, together with unexpected increases in public debt, inflation and interest rates, all increase the volatility of the country's risk premium. A sudden increase in volatility oppresses the economy, exerts deflationary pressures on consumer prices, and then a strong and sustained rise in public debt follows [20-22].

The premium for equity risk, but also the premium risk of the country, is an important factor for investors' decisions. The most reliable risk assessment can be found through three world-renowned rating agencies, working with the country's central bank. As the Czech Republic does not have a sufficient database, it is necessary to adjust the calculation methods to determine the risk premium, which will then be compared with Damodaran's methods.

\section{Data and methods}

The methodology is divided into two parts - the methods used in the Czech Republic and Damodaran's methods, which are clearly described and for which formulas with explanations are given. These applied methods will then be compared with each other.

As is well known, Damodaran [23] deals with risk premiums, and therefore the data needed for the calculation comes directly from his website, where it is regularly updated. Statistical data is secondary and is presented in a table, but also in a line chart, which shows the historical development of the country's risk premium values. The data contained in the example for the Czech Republic, which relates to inflation, is obtained from the Czech National Bank [24]. These are time series with annual observation. The data is publicly available and updated for the year 2020 .

\subsection{Risk premium methods in the Czech Republic}

Fotr and Soucek [25] stated that determining a company's risk premium is a bit more difficult in terms of the difficulty of determining the extent of business risk. The basic approach is based on the so-called CAPM (Capital Asset Pricing Model), i.e. the valuation of capital assets. The risk premium shall be determined based on the following formula:

$$
R P=\beta *\left(R_{m}-R_{d}\right)
$$


$\mathrm{R}_{\mathrm{m}}$ - average annual return on the equity market portfolio,

$\mathrm{R}_{\mathrm{d}}$ - average annual return on government bonds.

In practice, the so-called modular method is widely used, determining the risk premium as a sum of several components. There are multiple versions of this method. The first is the so-called comprehensive modular method, which determines the company's risk premium based on the evaluation of a set of at least twenty risk factors. These are divided into two groups of financial and business risk factors. Another version of the modular method is the INFA method, which determines the risk premium as the sum of four individual premiums, defined by financial indicators [25].

The CRP model can be used to determine the country risk premium. Petrik [26] points out that in the case of less developed and emerging markets, it is not easy to obtain the necessary volatility parameters, which are expressed by standard deviations of returns analyzed from a long-term perspective. This situation also applies to the Czech Republic. A universal starting point is proposed for these cases, which is based on the term in the formula below being replaced by a flat rate of 1.5 .

$$
\begin{gathered}
C R P=C D S_{n t} *\left(v s m_{n t} / v b m_{n t}\right) \\
C R P=C D S_{n t} * 1,5
\end{gathered}
$$

$\mathrm{CDS}_{\mathrm{nt}}-$ Credit Default Spread risk,

$\mathrm{Vsm}_{\mathrm{nt}}$ - Volatility of the stock market,

$\mathrm{Vbm}_{\mathrm{nt}}-$ Volatility of the bond market.

\subsection{Damodaran's methods}

In this part, three approaches according to Damodaran [14] will be discussed. In the first approach, Damodaran assumed that the default margin for a country was a good measure of the additional risk faced when investing in equity and in a selected country. The simplest and most widespread method is the standard spread that investors charge for the purchase of bonds issued by countries. This range can be estimated in one of three ways. The first is the current standard spread in the government bond market or in the CDS (Country Default Spread) market. The second method is the average (normalized) bond spread and the last method is the synthetic spread.

The second approach assumes a linear relationship between equity risk premiums and stock market standard deviations. It is therefore assumed that if the US risk premium can be calculated (e.g. through historical data), then the country risk premium and the equity risk premium for country $\mathrm{X}$ are as follows:

$$
\begin{gathered}
R S D_{\text {country } X_{X}}=\text { standard deviation }_{\text {country } X} / \text { standard deviation }_{U S A} \\
E R P_{\text {country } X}=\text { risk } \text { premium }_{U S A} * R S D_{\text {country } X} \\
C R P_{\text {country } X}=E R P_{\text {country } X}-\text { risk } \text { premium }_{U S A}
\end{gathered}
$$

The third approach combines the first two approaches and uses information from the country default spread and stock market volatility. This examines the relationship between stock market volatility and the volatility of the bond market used to estimate the spread. In this way, an estimate is obtained for the country equity risk premium. This relationship has already been expressed in the methods used also in the Czech Republic. 


\section{Results}

\subsection{Risk premium methods in the Czech Republic}

Marikova and Marik [27] found that in the Czech Republic it is necessary to examine the return on government bonds with a maturity of more than 10 years. It is more efficient in the calculation to use the average of several bonds with a similar maturity, as they provide more reliable data than when using only one bond.

Marikova and Marik [27] outline the calculation procedure typical for the Czech Republic. This procedure consists of four steps. For each step, current data is provided, which leads to the final result of the risk premium.

1. Find out the rating of the Czech Republic, which is published on the website of the Czech National Bank or on the individual websites of rating agencies. Currently, the rating is Aa3 or also AA-.

2. Project the country's rating into the value of the risk premium or the country's default risk. The difference between the return on bonds with the same rating as the Czech Republic and the US government bonds with the highest (Aaa) rating is used. Damodaran [23] states that the value of the country's default risk is $0.51 \%$.

3. Adjust the country default risk by the difference between stock market volatility and bond market volatility according to formula (2). For easier calculation, the fraction is replaced by an approximate coefficient of 1.5 according to formula (3). After reaching the numerical values, the country risk premium formula looks like this:

$$
\mathrm{CRP}=0.51 \% * 1.5=\mathbf{0 . 7 6 5} \%
$$

4. Adjust the country risk for differences in long-term projected inflation between the Czech Republic and the USA. The rate of inflation in the Czech Republic as of May 2020 is $2.6 \%$ and $2 \%$ in the USA. The difference in inflation is therefore $0.6 \%$. The country risk premium adjusted by the difference in inflation is:

CRP (adjusted by the inflation difference) $=0.765 \%+0.6 \%=\mathbf{1 . 3 6 5} \%$

5. The last part of the calculation is the sum of the average value of returns on US bonds, which is set at $4.88 \%$, and the country's risk premium.

Total risk premium of the Czech Republic $=4.88 \%+1.365 \%=\mathbf{6 . 2 4 5} \%$

\subsection{Damodaran's methods}

On his blog, Damodaran [23] provides data on individual countries, where the values of the equity risk premium (ERP), the country risk premium (CRP) and the country default spreads (CDS) are already calculated directly. Table 1 compares the data of the Czech Republic from 2018 and 2020, where there was a change in the rating. It's possible to say that the better the rating, the lower the risk premium.

Table 1. Data regarding the Czech Republic

\begin{tabular}{|c|c|c|}
\hline & Year 2018 & Year 2020 \\
\hline Moody's rating & $\mathrm{A} 1$ & $\mathrm{Aa} 3$ \\
\hline S \& P's rating & $\mathrm{AA}-$ & $\mathrm{AA}-$ \\
\hline CDS & $0.72 \%$ & $0.51 \%$ \\
\hline
\end{tabular}


Source: Own processing, according to Damodaran [23].

\begin{tabular}{|c|c|c|}
\hline CRP & $0.81 \%$ & $0.60 \%$ \\
\hline ERP & $5.89 \%$ & $5.80 \%$ \\
\hline
\end{tabular}

Table 2 presents the standard deviations of stocks and bonds.

Table 2. Standard deviations of stocks and bonds

\begin{tabular}{|c|c|}
\hline & Value \\
\hline$\sigma_{\text {equity }}$ & $13.82 \%$ \\
\hline$\Sigma_{\text {bond }}$ & $4.93 \%$ \\
\hline$\sigma_{\text {equity }} / \sigma_{\text {bond }}$ & 2.80 \\
\hline$\sigma(\mathrm{CDS})$ & $0.3475 \%$ \\
\hline$\sigma_{\text {equity }} / \sigma_{\mathrm{CDS}}$ & 0.32 \\
\hline
\end{tabular}

Source: Own processing, according to Damodaran [23].

Chart 2 below shows the values from the archive of Damodaran [23] in the period of years 2001 to 2019 . The output of the graph is the historical development of the country's risk premium value, which after 2010 is around 1.

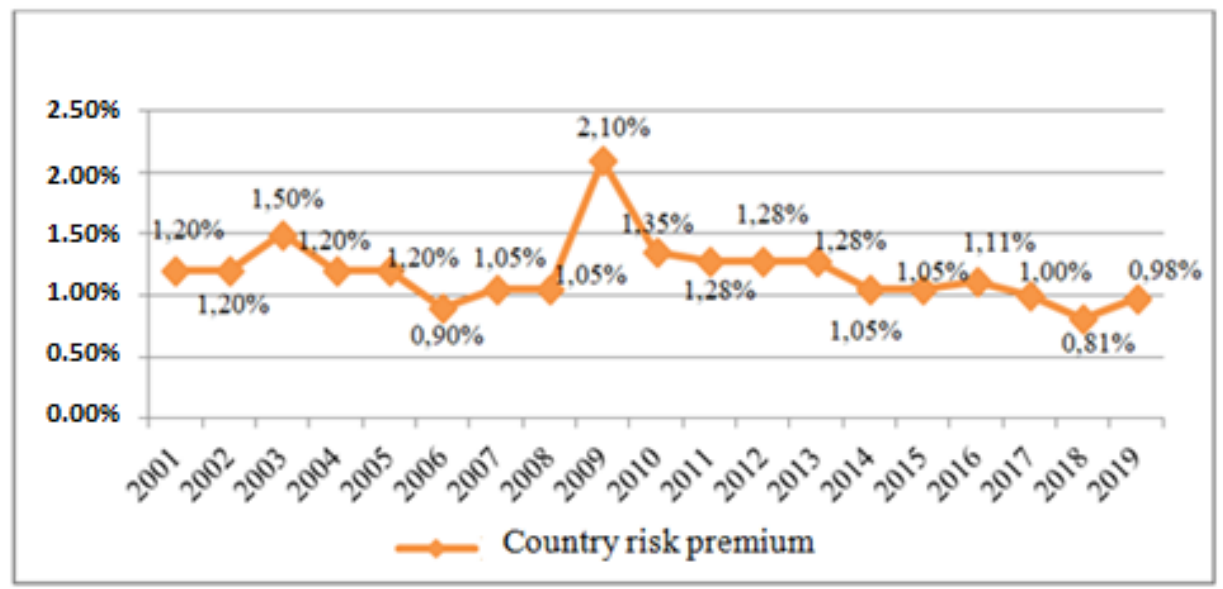

Fig. 4. Country risk premium development

Source: Own processing, according to Damodaran [23].

\subsection{Comparison between methods used in the Czech Republic and Damodaran's methods}

The CAPM model is used in the Czech Republic. It is used to value assets on capital markets and at the same time to inform the investor about the risk of assets. In the case of the country risk model, the value of summed volatilities is replaced by a coefficient of 1.5. This method of calculation is easier but less accurate, as the coefficient is only indicative. Damodaran's methods mainly feature data from the US capital market, as it has a long history. 


\section{Discussion}

For Czech as well as foreign investors, the easiest way to obtain a risk premium is to use the company's investment rating. Most large companies are rated by world-renowned rating agencies.

In the case of determining the risk premium of the Czech Republic, the easiest method is the CRP model. Most of the statistical data is stored together on Damodaran's website.

If the country's market does not have a long history or does not have such a developed capital market, it is recommended to apply data from the US capital market. However, I am inclined to the opinion of Marikova and Marik [27] that there are significant differences in the economy between Europe and the USA, so the data of an European country such as Germany, which has historical risk premium calculations, should be used.

According to Haskova and Vochozka [28], the economy of European countries is greatly influenced by the economic development of Germany. Austria, Belgium, France, Luxembourg, the Netherlands and Finland also have similar economic performance, with a similar impact on neighboring European countries.

\section{Conclusion}

Based on the achieved results of the risk premium in the environment of the Czech Republic, there is a noticeable difference in the results of this value when using individual methodological calculation procedures. One of the reasons for this inequality may be the coefficient of 1.5 used in the calculation of the CRP for the Czech Republic. Another problem may be the sum of US bond yield values and a country-specific risk premium. This conclusion therefore contributes to the criticism of the use of the values set by Damodaran on the basis of the economic situation of large US companies in setting the risk premium of other countries.

The aim of the contribution was thus met. In the future, other theoretical economists could focus on the methodology of determining the risk premium of a particular country, or at least for the European individual continents. However, when using the Damodaran calculation methodology, in many cases the problem is the absence of individual input data for the calculation of the risk premium, which would be relevant for a particular country. Even so, in countries outside the US, this result could be considered more accurate when using more relevant data.

\section{References}

1. A. Damodaran, Equity risk premiums (ERP) - Determinants, estimation and implications. Financial Markets, Institutions and Instruments, 18(5), 289-370 (2009)

2. M. Psarska, M. Vochozka, P. Sheng, Determining discount rate and investment evaluation in small and medium companies within Czech and Slovak conditions within the context of possible macroeconomic risks. Journal of Valuation and Expertness, 2(1), 28-47 (2017)

3. M. Marik et al., Metody oceňování podniku: proces ocenění, základní metody a postupy [Business valuation methods: valuation process, basic methods and procedures]. $2^{\text {nd }}$ ed. Prague: Ekopress (2007)

4. L. Kruschwitz, A. Löffler, G. Mandl, Damodaran's country risk premium: A serious critique. Business Valuation Review, 31(2-3), 75-84 (2012) 
5. M. Marik, P. Marikova, Přrirážky k diskontní míře - teoretické a praktické problémy modelu rizika země [Discount rate surcharges - theoretical and practical problems of the country risk model]. Odhadce a oceňování podniku [Appraiser and valuation of the company], 20(1), 5-17 (2014)

6. A. Damodaran, Equity Risk Premiums (ERP): Determinants, estimation and implications - The 2019 edition. SSRN Electronic Journal, (2019)

7. J. M. Chen, The equity risk premium and the equity premium puzzle. Finance and the Behavioral Prospect, 137-179 (2016)

8. J. Siegel, Perspectives on the equity risk premium. Financial Analysts Journal, 61(6), 61-73 (2005)

9. A. Damodaran, Value and risk: Beyond betas. Financial Analysts Journal, 61(2), 38-43 (2005)

10. T. Kliestik, K. Kocisova, M. Misankova, Logit and probit model used for prediction of financial health of company. Ekonomika a finance procedur, 23, 850-855 (2015)

11. T. Kliestik, The application of mathematical modeling to predict the financial health of bussinesses. Advances in Economics, Business and Management Research, 56, 298302 (2018)

12. A. Corelli, Company valuation. Analytical Corporate Finance, 257-295 (2018)

13. Ministry of Finance of the Czech Republic [online], Available at: www.mfcr.cz (2020)

14. A. Damodaran, Country risk: Determinants, measures and implications - the 2015 edition. SSRN Electronic Journal, (2015)

15. Czech National Bank [online], Ratingové ohodnocení vybraných zemí [Rating of selected countries], Available at: www.cnb.cz (2020)

16. Czech National Bank [online], Globální ekonomický výhled - únor 2020 [Global Economic Outlook - February 2020], Available at: www.cnb.cz (2020)

17. Euler Hermes [online], Risk maps by country, Available at: www.eulerhermes.com (2020)

18. A. Naumoski, Estimating the country risk premium in emerging markets: the case of the Republic of Macedonia. Financial Theory and Practice, 36(4), 413-434 (2012)

19. P. Palic, P. Posedel, M. Vizek, The determinants of country risk premium volatility: Evidence from a panel VAR model. Croatian Economic Survey, 19(1), 37-66 (2017)

20. P. Rousek, M. Vochozka, M. Psarska, Analysis of the consumption on the goods and services market in the cybernetic model of the 15 older EU member states. Ad Alta: Journal of Interdisciplinary Research, 9(1), 252-254 (2019)

21. P. Rousek, Analysis of Consumption on the Goods and Services Market in the Cybernetic Model of Selected Country. SHS Web of Conferences: Innovative Economic Symposium 2018 - Milestones and Trends of World Economy (IES2018) (2019)

22. P. Rousek, Cybernetic view of multipliers in macroeconomic theory. 12th International Days of Statistics and Economics, pp. 1506-1515 (2018)

23. A. Damodaran [online], Available at: http://pages.stern.nyu.edu/ adamodar/ (2020)

24. Czech National Bank [online], Prognóza ČNB z května 2020 [CNB forecast for May 2020], Available at: www.cnb.cz (2020)

25. J. Fotr, I. Soucek, Podnikatelský záměr a investiční rozhodování [Business plan and investment decisions]. Prague: Grada (2005) 
26. T. Petrik, Ekonomické a finanční řizení firmy [Economic and financial management of the company]. 2nd ed. Prague: Grada (2009)

27. P. Mariková, M. Marik, Diskontní míra pro výnosové oceňování podniku [Discount rate for revenue valuation of a company]. $1^{\text {st }}$ ed. Prague: Oeconomica (2007)

28. S. Haskova, M. Vochozka. Duality in cyclical trends in European Union confirmed. SAGE Open, 8(1), 1-7 (2018) 


\section{Appendix}

\begin{tabular}{|c|c|c|c|c|}
\hline & Moody's & & Standard \& Poor's & Fitch \\
\hline \multicolumn{5}{|c|}{ Investment grades } \\
\hline Aaa & $\begin{array}{l}\text { Australia, Canada, Denmark, } \\
\text { Germany, Luxembourg, N. Zealand, } \\
\text { Norway, Singapore, Sweden, } \\
\text { Switzerland, USA }\end{array}$ & AAA & $\begin{array}{l}\text { Australia, Denmark, Germany, } \\
\text { Liechtenstein, Luxembourg, } \\
\text { Netherlands, Norway. Singapore, } \\
\text { Sweden, Switzerland }\end{array}$ & $\begin{array}{l}\text { Australia, Canada, Denmark, Gemany, } \\
\text { Luxembourg, Netherlands, Norway, } \\
\text { Singapore, Sweden, Switzerland, USA }\end{array}$ \\
\hline Aa1 & Austria, Finland & $\mathrm{AA}^{+}$ & Austria, Finland, Hong Kong, USA & Austria, Finland \\
\hline Aa2 & $\begin{array}{l}\text { France, Kuwait, S. Korea, United } \\
\text { Kingdom }\end{array}$ & AA & $\begin{array}{l}\text { Belgium, France, Kuwait, N, } \\
\text { Zealand, S. Korea, United Kingdom }\end{array}$ & $\begin{array}{l}\text { Belgium, France, Hong Kong, Kuwait, } \\
\text { N. Zealand, S. Arabia, United Kingdom }\end{array}$ \\
\hline Aa3 & $\begin{array}{l}\text { Belgium, CZECH REPUBLIC, } \\
\text { Hong Kong, Chile, Qatar, Taiwan }\end{array}$ & AA- & $\begin{array}{l}\text { CZECH REPUBLC, Estcnia, } \\
\text { Ireland, Irael, Qatar, Slovenia, } \\
\text { Taiwan }\end{array}$ & CZECH REPLBLIC, Estonia, S, Korea \\
\hline A1 & $\begin{array}{l}\text { Estonia, China, Israel, Japan, S. } \\
\text { Arabia }\end{array}$ & $\mathrm{A}+$ & Chile, China, Japan, Slovakia & $\begin{array}{l}\text { Chile, China, Ireland, Istael, Malta, } \\
\text { Slovakia, Taiwan }\end{array}$ \\
\hline $\bar{A} 2$ & Ireland, Malta, Poland, Slovakia & A & Iceland, Lithuania & Iceland, Japan, Sloveria \\
\hline $\mathrm{A}^{3}$ & $\begin{array}{l}\text { Iceland, Latvia, Lithuania, } \\
\text { Malaysia, Mexico }\end{array}$ & A- & $\begin{array}{l}\text { Latvia, Malaysia, Malta, Poland, S. } \\
\text { Arabia, Spain }\end{array}$ & $\begin{array}{l}\text { Latvia, Lithuania, Malaysia, Poland, } \\
\text { Spain }\end{array}$ \\
\hline Baal & Slovenia, Spain & BBB + & Mexico & \\
\hline Baa2 & Bulgaria, India, Indonesia & BBB & Hungary, Indonesia, Italy, Portugal & $\begin{array}{l}\text { Bulgaria, Hungary, Indonesia, Italy, } \\
\text { Kazakhstan, Mexico, Portugal, Russia }\end{array}$ \\
\hline $\mathrm{Ba3}$ & $\begin{array}{lcl}\text { Hungary, } & \text { Italy, } & \text { Kazakhstan, } \\
\text { Portugal, Romania, } & \text { Russia, S. } \\
\text { Africa } & & \end{array}$ & BBB- & $\begin{array}{l}\text { Bulgaria, Croatia, Cprus, India, } \\
\text { Kazakhstan, Romania, Russa }\end{array}$ & Croatia, India, Romania \\
\hline \multicolumn{5}{|c|}{ Non-investment grades } \\
\hline Ba1 & & $\mathrm{BB}+$ & Serbia, S. Africa & $\begin{array}{l}\text { Cyprus, Northem Macedonia, Serbia, } \\
\text { S. Africa }\end{array}$ \\
\hline $\mathrm{Ba2}$ & Brazil, Croatia & BB & Vietnam & Brazil, Greece, Turkey, Vietnam \\
\hline Ba3 & Cyprus, Serbia, Vietnam & BB- & Brazil, Greece, Northem Macedonia & \\
\hline$\overline{B 1}$ & $\begin{array}{l}\text { Albania, Greece, Montenegro, } \\
\text { Turkey }\end{array}$ & $\mathrm{B}+$ & Albania, Montenegro, Turkey & Mongolia \\
\hline $\bar{B} 2$ & & B & $\begin{array}{l}\text { Argentina, Belarus, } \\
\text { Herzegovina, Egypt, Ukraine }\end{array}$ & Belarus, Egypt, Ukraine \\
\hline B3 & $\begin{array}{l}\text { Belarus, Bosnia - Herzegovina, } \\
\text { Egypt, Moldova, Pakistan }\end{array}$ & B- & Mongolia, Pakistan & Pakistan \\
\hline Caal & Mongolia, Ukraine & $\mathrm{CCC}+$ & & \\
\hline $\mathrm{Ca2}$ & Argentina, Cuba & $\mathrm{CCC}$ & & Argentina \\
\hline $\mathrm{Caa3}$ & & $\mathrm{CCC}$ & & \\
\hline $\mathrm{Ca}$ & & $\mathrm{CC}$ & & \\
\hline
\end{tabular}

Fig. 5. Credit rating of countries

Source: Own processing, according to Czech National Bank [15]. 